\title{
Using Expression Profiling to Understand the Effects of Chronic Cadmium Exposure on MCF-7 Breast Cancer Cells
}

\author{
Zelmina Lubovac-Pilavi", Daniel M. Borràs ${ }^{1}$, Esmeralda Ponce ${ }^{2}$, Maggie C. Louie ${ }^{2,3^{*}}$ \\ 1 Systems Biology Research Centre - Bioinformatics, School of Bioscience, University of Skövde, Skövde, Sweden, 2 Department of Natural Sciences and \\ Mathematics, Dominican University of California, San Rafael, California, United States of America, 3 College of Pharmacy, Touro University of California, \\ Vallejo, California, United States of America
}

\begin{abstract}
Cadmium is a metalloestrogen known to activate the estrogen receptor and promote breast cancer cell growth. Previous studies have implicated cadmium in the development of more malignant tumors; however the molecular mechanisms behind this cadmium-induced malignancy remain elusive. Using clonal cell lines derived from exposing breast cancer cells to cadmium for over 6 months (MCF-7-Cd4, -Cd6, -Cd7, -Cd8 and -Cd12), this study aims to identify gene expression signatures associated with chronic cadmium exposure. Our results demonstrate that prolonged cadmium exposure does not merely result in the deregulation of genes but actually leads to a distinctive expression profile. The genes deregulated in cadmium-exposed cells are involved in multiple biological processes (i.e. cell growth, apoptosis, etc.) and molecular functions (i.e. cadmium/metal ion binding, transcription factor activity, etc.). Hierarchical clustering demonstrates that the five clonal cadmium cell lines share a common gene expression signature of breast cancer associated genes, clearly differentiating control cells from cadmium exposed cells. The results presented in this study offer insights into the cellular and molecular impacts of cadmium on breast cancer and emphasize the importance of studying chronic cadmium exposure as one possible mechanism of promoting breast cancer progression.
\end{abstract}

Citation: Lubovac-Pilav Z, Borràs DM, Ponce E, Louie MC (2013) Using Expression Profiling to Understand the Effects of Chronic Cadmium Exposure on MCF-7 Breast Cancer Cells. PLoS ONE 8(12): e84646. doi:10.1371/journal.pone.0084646

Editor: Jian Jian Li, University of California Davis, United States of America

Received September 30, 2013; Accepted November 25, 2013; Published December 20, 2013

Copyright: $\odot 2013$ Lubovac-Pilav et al. This is an open-access article distributed under the terms of the Creative Commons Attribution License, which permits unrestricted use, distribution, and reproduction in any medium, provided the original author and source are credited.

Funding: This work was supported in part by the National Cancer Institute (CA121983-02 to MCL and CA121983-02S1 to EP), and from Magnus Bergvall stiftelse and AG fonden to ZL. The funders had no role in study design, data collection and analysis, decision to publish, or preparation of the manuscript.

Competing interests: The authors have declared that no competing interests exist.

*E-mail: maggie.louie@dominican.edu (MCL); zelmina.lubovac@his.se (ZL)

\section{Introduction}

The International Agency for Research on Cancer and the National Toxicology Program of the United States of America have classified cadmium as a category I human carcinogen $[1,2]$ because increasing evidence shows both occupational and non-occupational exposure to cadmium are associated with cancers of the lung, prostate, pancreas, kidney, liver, stomach, and urinary bladder [3-9]. Cadmium exposure has also been correlated with an increase in the incidence of breast cancer [10-12]. Recent studies have identified significantly higher levels of cadmium in tumor tissues as well as in other biological samples from tumor patients $[8,13,14]$. Specifically, Strumylaite et al. found that patients with malignant breast cancer had accumulated significantly higher levels of cadmium when compared to patients with benign tumors [13] offering further support for a possible relationship between cadmium and breast cancer progression.
Several studies have shown that cadmium has the ability to mimic the biological functions of estrogen in breast cancer cells by activating the estrogen receptor [11,15-20]. Previous work from our lab and others has suggested that cadmium can promote MCF-7 breast cancer cell growth via ERa [11,16,19]. Animal studies have revealed that, similar to estrogen, cadmium promotes neoplastic growth, increases uterine weight, induces changes in the uterine lining, and increases the density of mammary glands in rats and mice [17,21-23]. Collectively, these studies demonstrate that cadmium functions as a hormone-disruptor and metalloestrogen and is an important contributor to the development of breast cancer.

Several studies have also shown that cadmium exposure is associated with the development of more malignant tumors $[6,24,25]$. Furthermore, results from our recent study have suggested that cells chronically exposed to cadmium acquire a more metastatic phenotype that includes an increased ability to migrate and invade [20]. We demonstrated that prolong 
exposure to cadmium induces cellular changes brought about by changes in the expression of genes such as SDF-1; however a comprehensive molecular understanding of how chronic exposure to cadmium mediates these changes in phenotype remains unclear.

In this study, microarray analysis was used to investigate the effect of prolonged cadmium exposure on gene expression by comparing the global gene expression of MCF-7 breast cancer cells chronically exposed to cadmium with that of control MCF-7 cells. Genes that were differentially expressed in cadmium-adapted cells were further analyzed.

\section{Materials and Methods}

\section{Cell Culture}

MCF-7 cells were obtained from American Type Culture Collection (ATCC, Manassas, VA). MCF-7 cells were maintained in complete media: Dulbecco's Modified Eagle Medium (DMEM) plus $10 \%$ fetal bovine serum and $1 \%$ penicillin and streptomycin (Hyclone, Logan, UT). Cadmiumadapted cell lines (MCF-7-Cd4, -Cd6, -Cd7, -Cd8 and -Cd12) were derived as previously described [20], and maintained in complete media but supplemented with $10^{-7} \mathrm{M} \mathrm{CdCl}_{2}$.

\section{Affymetrix Microarray}

Equal numbers of MCF-7 and MCF-7-Cd4, -Cd6, -Cd7, -Cd8, and $-\mathrm{Cd} 12$ cells were plated in $10 \mathrm{~cm}$ plates and semisynchronized by serum starvation. Twenty-four hours later, media containing hormone (DMEM+ 10\% FBS) were added back to cells. Cells were harvested 10 hours later for total RNA isolation using Direct-zol ${ }^{\mathrm{TM}}$ RNA MiniPrep (Zymo Research Corporaton, Irvine, CA) according to manufacturer's protocol. In short, cells were lysed with TRI-Reagent and mixed with equal volume of $100 \%$ ethanol. Mixture was transferred to a Direct-zol column and following several washes, total RNA was eluted using nuclease-free water. Microarray experiments were performed by the QB3-Functional Genomics Lab at UC Berkeley (Berkeley, CA) using GeneChip ${ }^{\circledR}$ Human Gene 1.0 ST arrays (Affymetrix, Santa Clara, CA). Expression signals were extracted and normalized by means of the Expression Console software (Affymetrix) applying the Robust Multichip Average (RMA) normalization method [26]. The complete microarray expression data are available at the NCBI's Gene Expression Omnibus (GEO) (accession GSE52404).

\section{Quantitative Reverse Transcriptase-Polymerase Chain Reaction (qRT-PCR)}

Total RNA was isolated from cells using Direct-zol RNA MiniPrep kit according to manufacturer's protocol (Zymo Research Corporation, Irvine, CA). Three micrograms $(\mu \mathrm{g})$ of total RNA were used for the reverse transcription reaction with oligo-dT ${ }_{18}$ primers and Moloney Murine Leukemia Reverse Transcriptase (M-MLV RT, Promega, Madison,WI). Gene expression was monitored using SYBR-green based qRT-PCR (Viia-7; Applied Biosystems, Life Technologies, Grand Island, NY). All primers were synthesized by Integrated DNA
Table 1. Primer Sequences.

\begin{tabular}{|c|c|}
\hline $\mathbf{M T 1 X}_{\mathbf{F}}$ :CTCTTGATCGGGAACTC & MT1X $_{\mathbf{R}}:$ GGTTGCTCTATTTACATCTG \\
\hline $\begin{array}{l}\text { ANXA3 } \\
\text { F :ATGCCCAGATTCTCTATAA }\end{array}$ & ANAX3 ${ }_{R}:$ GATCTGGACACCATTATTC \\
\hline MT2A F:AACCTGTCCCGACTCTA & 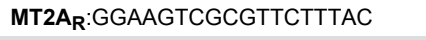 \\
\hline $\begin{array}{l}\text { CCNE2 } \\
\text { F:GGGAGTACCAAAGAAATTAT }\end{array}$ & CCNE2 $_{2}:$ AGTTTAGGTCAAGTGTTAAG \\
\hline CCNB1F: & CCNB1 $_{R}:$ GAC TAC ATT CTT AGC CAG \\
\hline GTACCCTCCAGAAATTGGTGA & GTG \\
\hline $\begin{array}{l}\text { BUB1 F: } \\
\text { GGCTCCTACACTTCCTGATATTT }\end{array}$ & BUB1R: CTGGCTCCTGTGGGTTTATT \\
\hline $\begin{array}{l}\text { CENPF } \mathbf{F}: \\
\text { GTTCAAGAAGCTGGAGATAG }\end{array}$ & CENPF $_{\mathbf{R}}: C C C T C G G G A A T C T T G T T T A G$ \\
\hline
\end{tabular}

Technologies, Inc. (IDT; San Diego, CA). The primer sequences are listed in Table 1.

\section{Hierarchical clustering}

Hierarchical clustering of the samples was performed to determine if cadmium exposed samples could be separated from the control samples. Clustering was performed with Javabased desktop application MultiExperiment Viewer (MeV) [27] by using the average linkage rule and Pearson correlation as the similarity metric.

\section{Identifying differentially expressed (DE) genes}

To understand the effects of chronic cadmium exposure on gene expression in breast cancer, two control MCF-7 parental cell lines and five different clonal cadmium-adapted cell lines (MCF-7-Cd4, -Cd6, -Cd7, -Cd8, and -Cd12)- previously derived from cells chronically exposed to cadmium- were used for microarray analysis. Expression signals were extracted and normalized by means of the Expression Console software (Affymetrix) applying the Robust Multichip Average (RMA) normalization method [26]. The data were background corrected, normalized (Quantile) and summarized (MedianPolish). Differentially expressed genes were identified with Significance Analysis of Microarrays - SAM [27,28]. SAM relies on a modified $t$-test to determine the significance of the expression level of each gene. SAM then uses permutations to estimate the false discovery rate (FDR) [29] i.e. the fraction of false positive genes. Cut-off for FDR was set to 0.05 in order to identify genes with significantly aberrant expression levels to be further analyzed.

\section{Functional enrichment of the DE genes}

A total of 795 DE genes were used as input for further analysis. A singular enrichment analysis (SEA) was applied to identify the annotation terms that are overrepresented in our gene list. Following SEA, two additional enrichment analysis tools were used; the first was Database for Annotation, Visualization and Integrated Discovery (DAVID; http:// david.abcc.ncifcrf.gov/) [30], which relies on a modified Fisher's exact test (EASE score), and the second is Onto-Express 


\section{Figure 1}

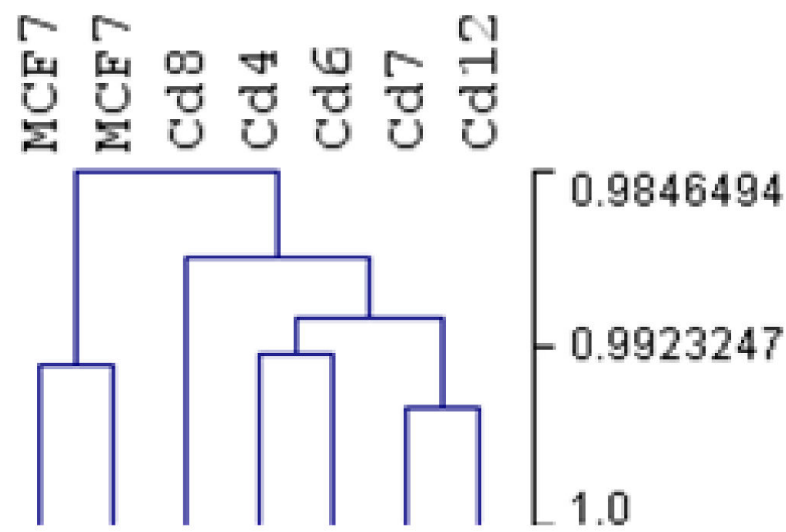

Figure 1. Dendrogram of hierarchical clustering showing a clear distinction between control MCF-7 and cells chronically exposed to cadmium.

doi: 10.1371/journal.pone.0084646.g001

[31,32] (http://vortex.cs.wayne.edu/projects.htm) which implements a hypergeometric statistical method. Both of the tools rely on Gene Ontology (GO) as a primary annotation source, but also integrate other annotation sources.

Furthermore, genes that are known to be associated with breast cancer were identified using Genes-to-Systems Breast Cancer Database - G2SBC (http://www.itb.cnr.it/breastcancer/) [33], which gathers information about genes that have been previously reported in literature to be associated with breast cancer. Gene Expression Atlas - GXA (http://www.ebi.ac.uk/ gxa) from EMBL-EBI database [34] was also used for further investigation of $D E$ genes by searching for previously described gene expression patterns associated with different biological/experimental conditions, such as estrogen expression.

\section{Results}

\section{Hierarchical clustering}

We performed hierarchical clustering of the samples to see if there is a separation between control MCF-7 cells and those treated with cadmium for over 6 months. Figure 1 shows a dendogram with two major branches, confirming the discrimination between control and cadmium-treated samples. This suggests that genes differentially expressed in breast cancer cells chronically exposed to cadmium can be identified using this set of microarray data.

\section{Identifying differentially expressed genes}

SAM analysis was used to identify differentially expressed (DE) genes, and this revealed $944 \mathrm{DE}$ genes at $\mathrm{FDR}<0.05$. Among these are 371 over-expressed and 573 are under-
Table 2. 30 over-expressed genes with lowest $q$-value.

\begin{tabular}{|c|c|c|c|}
\hline Gene symbol & FClog & $q$-value & Gene description \\
\hline ANXA3 & 2.15 & $0.00 \mathrm{E}+00$ & annexin $\mathrm{A} 3$ \\
\hline ULBP2 & 1.65 & 1.67E-02 & UL16 binding protein 2 \\
\hline MT1F & 1.46 & 1.67E-02 & metallothionein $1 \mathrm{~F}$ \\
\hline SCARNA9 & 1.23 & 1.67E-02 & small Cajal body-specific RNA 9 \\
\hline MT1L & 1.21 & $1.42 \mathrm{E}-02$ & metallothionein $1 \mathrm{~L}$ \\
\hline$\underline{D K K 1}$ & 1.18 & $1.42 \mathrm{E}-02$ & dickkopf homolog 1 \\
\hline PDLIM1 & 0.98 & $1.51 \mathrm{E}-02$ & PDZ and LIM domain 1 \\
\hline PTP4A3 & 0.98 & 1.67E-02 & $\begin{array}{l}\text { protein tyrosine phosphatase type IVA, } \\
\text { member } 3\end{array}$ \\
\hline ANXA2P2 & 0.97 & $1.42 \mathrm{E}-02$ & annexin A2 pseudogene 2 \\
\hline MT1X & 0.97 & 5.87E-03 & metallothionein $1 \mathrm{X}$ \\
\hline PRSS8 & 0.90 & $6.81 \mathrm{E}-03$ & protease, serine, 8 \\
\hline CERCAM & 0.85 & $1.42 \mathrm{E}-02$ & cerebral endothelial cell adhesion molecule \\
\hline CRABP1 & 0.83 & 1.67E-02 & cellular retinoic acid binding protein 1 \\
\hline CBFA2T3 & 0.79 & $1.51 \mathrm{E}-02$ & $\begin{array}{l}\text { core-binding factor, runt domain, alpha subunit } \\
2 \text {; transloc to } 3\end{array}$ \\
\hline DECR1 & 0.76 & $1.64 \mathrm{E}-02$ & 2,4-dienoyl CoA reductase 1 \\
\hline FSTL3 & 0.75 & 1.19E-02 & follistatin-like 3 \\
\hline$\underline{U C P 2}$ & 0.73 & $1.64 \mathrm{E}-02$ & uncoupling protein 2 \\
\hline FKBP9 & 0.73 & $1.62 \mathrm{E}-02$ & FK506 binding protein 9 \\
\hline ZNF286B & 0.71 & 1.67E-02 & zinc finger protein $286 \mathrm{~B}$ \\
\hline MT2A & 0.66 & $0.00 \mathrm{E}+00$ & metallothionein $2 \mathrm{~A}$ \\
\hline TRADD & 0.62 & 1.19E-02 & TNFRSF1A-associated via death domain \\
\hline CRYL1 & 0.62 & $1.42 \mathrm{E}-02$ & crystallin, lambda 1 \\
\hline ZNHIT2 & 0.59 & 1.67E-02 & zinc finger, HIT-type containing 2 \\
\hline ATP2A3 & 0.54 & 1.67E-02 & ATPase, $\mathrm{Ca}++$ transporting, ubiquitous \\
\hline$\underline{S R D 5 A 1}$ & 0.53 & 1.64E-02 & steroid-5-alpha-reductase, alpha polypeptide 1 \\
\hline RAB32 & 0.52 & 1.67E-02 & RAB32, member RAS oncogene family \\
\hline TMEM8A & 0.49 & $1.58 \mathrm{E}-02$ & transmembrane protein $8 \mathrm{~A}$ \\
\hline ZP1 & 0.49 & 1.19E-02 & zona pellucida glycoprotein 1 (sperm receptor) \\
\hline SLC15A4 & 0.45 & 1.19E-02 & solute carrier family 15 , member 4 \\
\hline CCNE1 & 0.45 & $1.51 \mathrm{E}-02$ & cyclin E1 \\
\hline
\end{tabular}

Underlined genes are known to be associated with breast cancer.

doi: 10.1371/journal.pone.0084646.t002

expressed genes. The gene list was then filtered by removing duplicate gene symbols resulting in 795 DE genes (Table S1), which were used for further analysis. Table 2 shows a list of the top 30 over-expressed genes, along with the associated $q$ value (measure of significance in terms of false discovery rate), fold change log (FClog) and gene description. A corresponding list of 30 under-expressed genes can be found in Table 3. For a complete list of DE genes, see supplemental information (Table S1).

Amongst the over-expressed genes in Table 2, some genes are expected to show differential gene expression after cadmium exposure, including those associated with endocrine disruption and heavy metal toxicity. Prior to identifying these genes, an initial search of all listed genes was done using Gene Expression Atlas (GXA) to find genes with expression patterns associated with estrogenic effects and metal/cadmium toxicity. In the case of endocrine disruption effects, the genes that were up-regulated and associated with this function include ULBP2, MT1F, DKK1, PDLIM1, PTP4A3, ANXA2P2, 
Table 3. 30 under-expressed genes with lowest $q$-value.

\begin{tabular}{llll}
\hline & & & \\
\hline Gene symbol & FClog & $q$-value & Gene description \\
\hline SH3GL3 & -0.52 & $5.16 \mathrm{E}-03$ & SH3-domain GRB2-like 3 \\
NPSR1 & -0.62 & $0.00 \mathrm{E}+00$ & neuropeptide S receptor 1 \\
\hline TK1 & -0.62 & $6.47 \mathrm{E}-03$ & thymidine kinase 1, soluble \\
\hline RHEBL1 & -0.65 & $0.00 \mathrm{E}+00$ & Ras homolog enriched in brain like 1 \\
GPR128 & -0.68 & $5.54 \mathrm{E}-03$ & G protein-coupled receptor 128 \\
\hline REXO1L2P & -0.73 & $5.62 \mathrm{E}-03$ & REX1, RNA exonuclease 1 homolog (S. \\
cerevisiae)-like 2
\end{tabular}

MT1X, PRSS8, CERCAM, CRABP1, CBFA2T3, DECR1, FSTL3, UCP2, FKBP9, ZNF286B, MT2A, TRADD, CRYL1, ZNHIT2, ATP2A3, SRD5A1, RAB32, ZP1, SLC15A4, CCNE1 and ANXA3 (Table 2), while genes SH3GL3, TK1, CYP24A1, PGK1, TAF9B, SSX2, TBX4, SPDYE1, RHEBL1 and ABCA6 were down-regulated (Table 3 ). We also identified DE genes associated with heavy metal toxicity and these genes include MTJF, MT1L, MT1X, and MT2A which are up-regulated (Table 2), while CYP24A1 and TK1 genes associated with calcium homeostasis and zinc binding, respectively are down-regulated (Table 3).

Apart from this, several of the DE genes were already known to be associated with breast cancer, not unexpected since cadmium has been shown to be involved in the development and progression of breast cancer $[17,19,20,35,36]$. Among the genes in Table 2, eight are known to be associated with breast cancer including: ANXA3 (Annexin A3), an inhibitor of phospholipase A2; DKK1 (Dickkopf), a precursor protein that inhibits the Wnt signaling pathway; PDLIM1 (DZ and LIM domain protein 1), a protein that has been shown to interact with ERa; CRABP1 (cellular retinoic acid-binding protein), a protein that may play a role in retinoic acid-mediated differentiation and proliferation; SRD5A1 (5-a reductase type 1), an enzyme involved in the metabolism of progesterone; MT2A (metallothionein 2A), metal response protein; UCP2 (uncoupling protein 2), an inner mitochondrial membrane anion carrier that negatively regulates reactive oxygen species production; and CCNE1 (cyclin E1), a G1/S cyclin that regulates cell cycle progression. Two additional genes in Table 3- TKI (Thymidine kinase 1) and PGK1 (Phosphoglycerate kinase 1) - are also known to be associated with breast cancer. Other than the genes highlighted in Tables 2 and 3, analysis of the complete list of DE genes identified an additional 87 genes with known breast cancer association. These are all summarized in the heat map shown in Figure 2. Specifically, the heat map is used to highlight the expression pattern of breast cancer associated genes in the cadmium samples in comparison to the control samples with the dendrogram of the genes shown on the left-hand side, and the dendrogram on top depicting the different samples. Hierarchical clustering method based on Pearson dissimilarity metric was used to create the dendrograms. The heat map also indicates that the set of breast cancer associated genes follows similar expression pattern as the whole set of DE genes, clearly separating control cells from cadmium-exposed cells. This subset of genes is differentially expressed in all five clonal cadmium cell lines suggesting that a common gene expression signature does exist in cells chronically exposed to cadmium.

\section{Functional enrichment analysis of the DE genes}

We performed gene annotation enrichment analysis of DE genes, focusing on Gene Ontology (GO), which is the de facto method for functional annotation and also used as a primary annotation source in the majority of enrichment tools. Initially, we applied DAVID to identify significant annotation terms GO molecular function (GO MF) and GO biological process (GO BP) terms - with the purpose of finding important biological functions and processes that characterize the impact of the DE genes identified in our study. Out of $795 \mathrm{DE}$ genes, there were 783 hits found in DAVID. We applied a cut-off $p<0.05$ to derive significantly over-represented GO MF and GO BP terms (Figure $3 \mathrm{~A}$ and $\mathrm{B}$ ). Among the GO BP terms identified by DAVID, the most significantly enriched term is "regulation of fibroblast proliferation" ( $p$-value $=2.29 \mathrm{E}-04)$, with 8 genes assigned to it. One of the up-regulated genes in this set is IFI30, interferon gamma-inducible protein 30 , which is linked to breast cancer $[37,38]$. Other GO BP terms of interest include "cell division" (19 genes), "nuclear division" (18 genes), and "Gprotein coupled receptor protein signaling pathway" (58 genes). Many of the genes assigned with these terms are known to contribute to cancer cell growth and development. Among the most significantly enriched GO MF terms are the "cadmium ion 


\section{Figure 2}

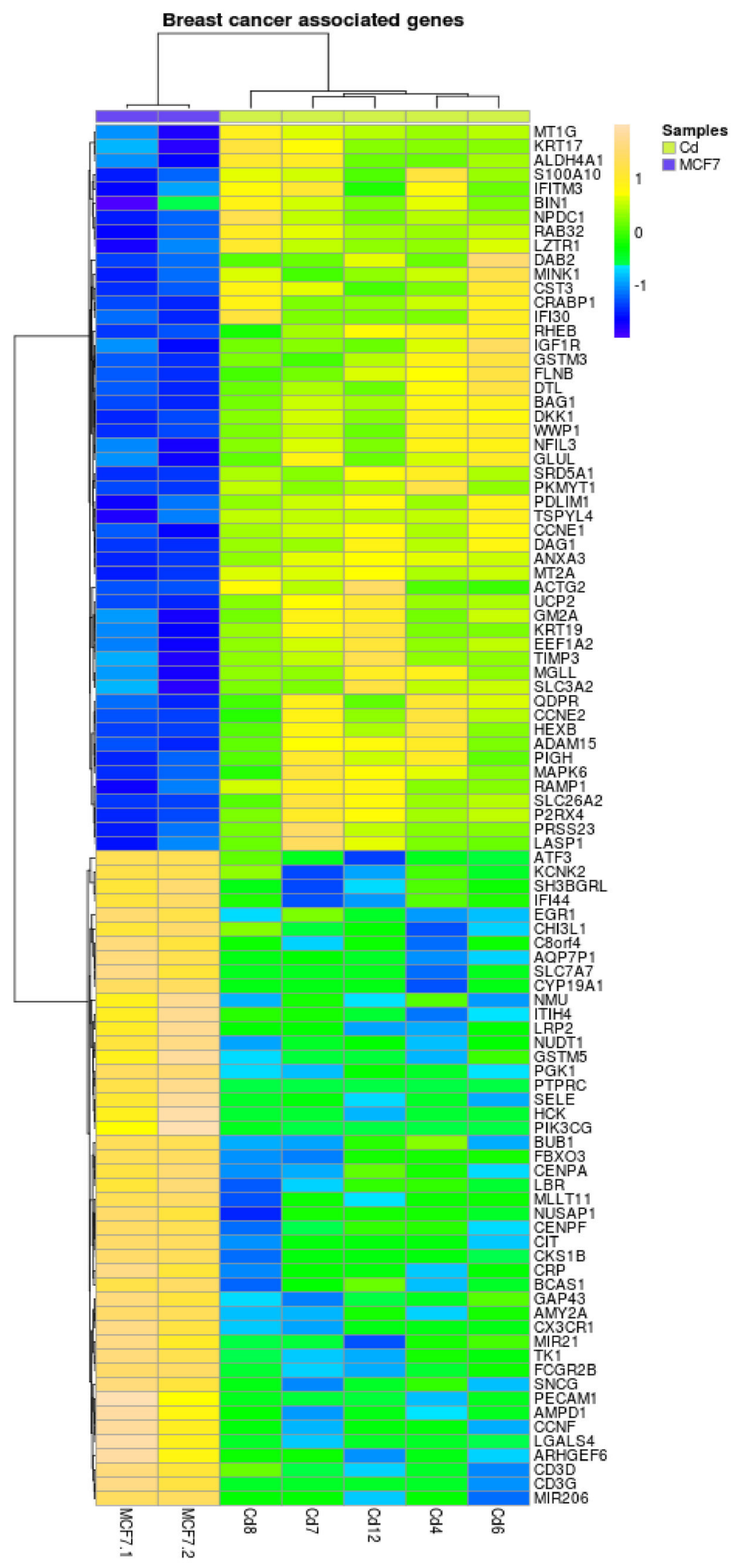

Figure 2. Heat map showing expression of 97 breast cancer associated genes that are differentially expressed between control and cadmium-adapted cells. Each row represents a gene and each column represents a sample.

doi: 10.1371/journal.pone.0084646.g002 
binding" ( $p=1.6 \mathrm{E}-05)$ and "copper ion binding" ( $p=2.5 \mathrm{E}-04)$ (Figure 3A).

A more in-depth analysis of the DE genes was done using Onto-Express, which also provides graphical tree view for GO terms, with the ability to browse functional profiles of the GO tree at different abstraction levels. Results in Figures 4 and 5 represent the identified GO MF and GO BP terms amongst the $D E$ genes, along with the number of under- and overexpressed genes for each identified term using Onto-Express. In the final GO annotation analysis, we combined the results from DAVID with Onto-Express to derive the overrepresented GO categories. Among the GO MFs of interest are the "cadmium ion binding", "metal ion binding, "zinc ion binding", and "calcium ion binding" genes. The GO BP categories of interest include "cell division", "cell proliferation", and "cell cycle". We further evaluated these GO categories. Table 4 shows the four GO MFs associated with the metal/cadmium response, and the list of genes in each of the categories; and Table 5 shows the three GO BPs linked to cell growth and the respective genes in each category.

\section{Confirmation of DE genes using quantitative RT-PCR}

Differential expression of some of the genes identified in Tables 4 and 5 was further verified using quantitative RT-PCR. Total RNA from both parental MCF-7 and cadmium-exposed cell lines was isolated for gene expression analysis using gene specific primers and SYBR-green based quantitative-PCR. Relative fold changes were calculated based on expression levels in parental MCF-7 cells and subsequently normalized to the housekeeping gene, GAPDH (glyceraldehyde dehydrogenase). Consistent with Table 4, results in Figure 6A confirm that the expressions of ANXA3, MT1X and MT2A were elevated in cells chronically exposed to cadmium, with fold changes ranging from 2 - to 10 -fold $(p<0.001)$. Figure 6B shows the fold changes of cell cycle related genes- CCNE2, CCNB1, BUB1 and CENPF $(p<0.001)$. Among these genes, only CCNE2 is up-regulated in cells chronically exposed to cadmium, whereas CCNB1, BUB1 and CENPF are all downregulated. Specific fold changes are summarized in Table 6 for each of the cadmium cell lines.

\section{Discussion}

Multiple studies have suggested that cadmium functions as a metalloestrogen, mimicking the actions of estrogen to promote breast cancer cell proliferation via the activation of the estrogen receptor (ERa) [16,18,19]. Additionally, studies have also demonstrated that exposure to cadmium is associated with the development of more malignant tumors $[6,24,25]$. While acute cadmium exposure and correlation studies exist at the tumor tissue level, there are very few cellular models aimed at studying chronic cadmium exposure and breast cancer. We have previously developed clonal cadmium cell lines (MCF-7$\mathrm{Cd} 4,-\mathrm{Cd} 6,-\mathrm{Cd} 7,-\mathrm{Cd} 8$ and -Cd12), derived from cells exposed to cadmium for over 6 months, which serve as a cell culture model to study chronic cadmium exposure [20]. While we have previously demonstrated that prolonged exposure to cadmium induces cellular changes [20]- most likely due to changes in gene expression - the impacts of chronic cadmium exposure on global gene expression remains unclear. To establish expression profiles of cells chronically exposed to cadmium, we used microarray analysis to investigate the effects of prolonged cadmium exposure on gene expression in comparison with control MCF-7 breast cancer cells. High throughput microarray technology is commonly used to identify differentially expressed genes, and previous research using microarray platforms has demonstrated its potential in case-controlled gene expression comparisons [39,40]. Hierarchical clustering analysis of the microarray data (Figure 1) confirmed that distinct expression patterns exist between parental MCF-7 and cadmium-adapted cells, thus warranting further analysis.

Results in Tables 2 and 3 provide an abbreviated lists of over- and under-expressed genes in cells chronically exposed to cadmium. Genes with known associations to breast cancer were identified using Genes-to-Systems Breast Cancer Database- G2SBC (http://www.itb.cnr.it/breastcancer/), which contains information about genes that have been previously reported in the literature to be associated with breast cancer. Furthermore, Gene Expression Atlas (GXA) from EMBL-EBI database [34] was used to further investigate DE genes by searching for previously described gene expression patterns associated with breast cancer and different biological/ experimental conditions, such as estrogen treatment. Genes associated with breast cancer were then organized and represented in a heat map (Figure 2), and similar to the hierarchical clustering in Figure 1, there is a clear expression pattern among the breast cancer associated genes in cadmium-exposed samples. Interestingly, among the overexpressed genes (Table 2), MT2A (metallothionein 2A) and CCNE1 (cyclin E1) are associated not only with breast cancer, but also with cadmium induction [19,41-43] suggesting that the microarray analysis is identifying genes relevant to both cadmium exposure and breast cancer.

More in-depth analysis was accomplished using functional annotations; and an initial overview of the functional annotation of DE genes in terms of molecular functions and biological processes was obtained by using DAVID (Figure 3). Since Gene Ontology (GO) is the de facto method for functional annotation, tools that primarily use GO as their annotation resource were initially used in gene enrichment analysis. As there is no standard to determine which functional enrichment analysis tools should be used, it is advantageous to run more than one tool in order to compensate for any weaknesses. DAVID was used for an initial analysis to identify the most significantly enriched terms, but because of high stringency, there is a risk for neglecting some weakly enriched terms, which may bias the biological conclusion. Therefore, we also performed a functional annotation analysis using Onto-Express (Figure 4 and 5) to give us a broader picture of cadmium's effect. The results from DAVID complemented the results from Onto-Express which allow customized analysis with the possibility of collapsing or expanding GO term nodes (and calculate corresponding $p$-values) to give us more in-depth analysis of the DE genes.

From this analysis, we identified GO categories of interest, including genes that are associated with cadmium and other 


\section{Figure 3}

\section{A. GO Molecular Function}

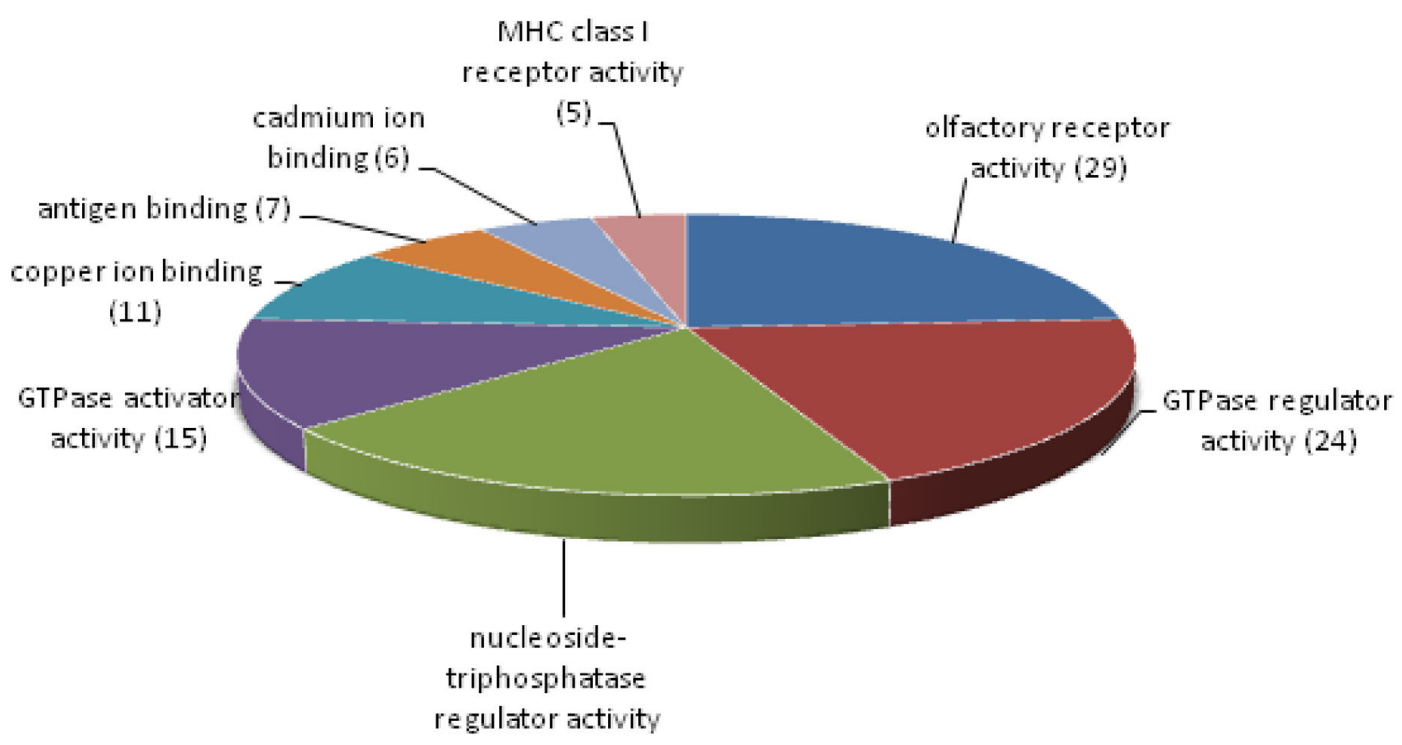

(24)

\section{B. GO Biological Process}

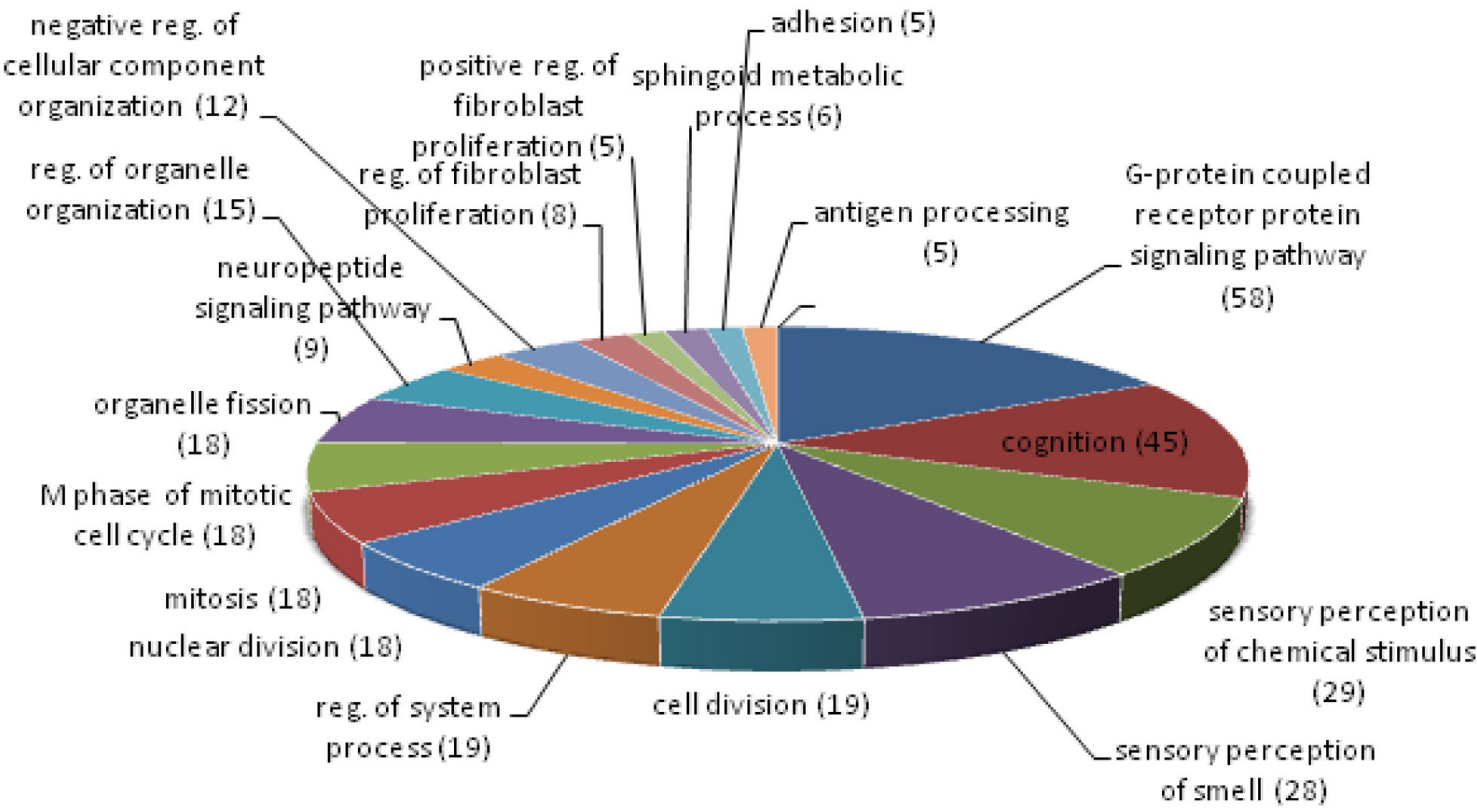

Figure 3. Over-represented Gene Ontology (GO) annotation among differentially expressed genes. GO categories identified using Database for Annotation, Visualization and Integrated Discovery (DAVID; http://david.abcc.ncifcrf.gov/). A) Biological Process and B) Molecular Function.

doi: 10.1371/journal.pone.0084646.g003 


\section{Figure 4}

\section{GO Molecular Function}

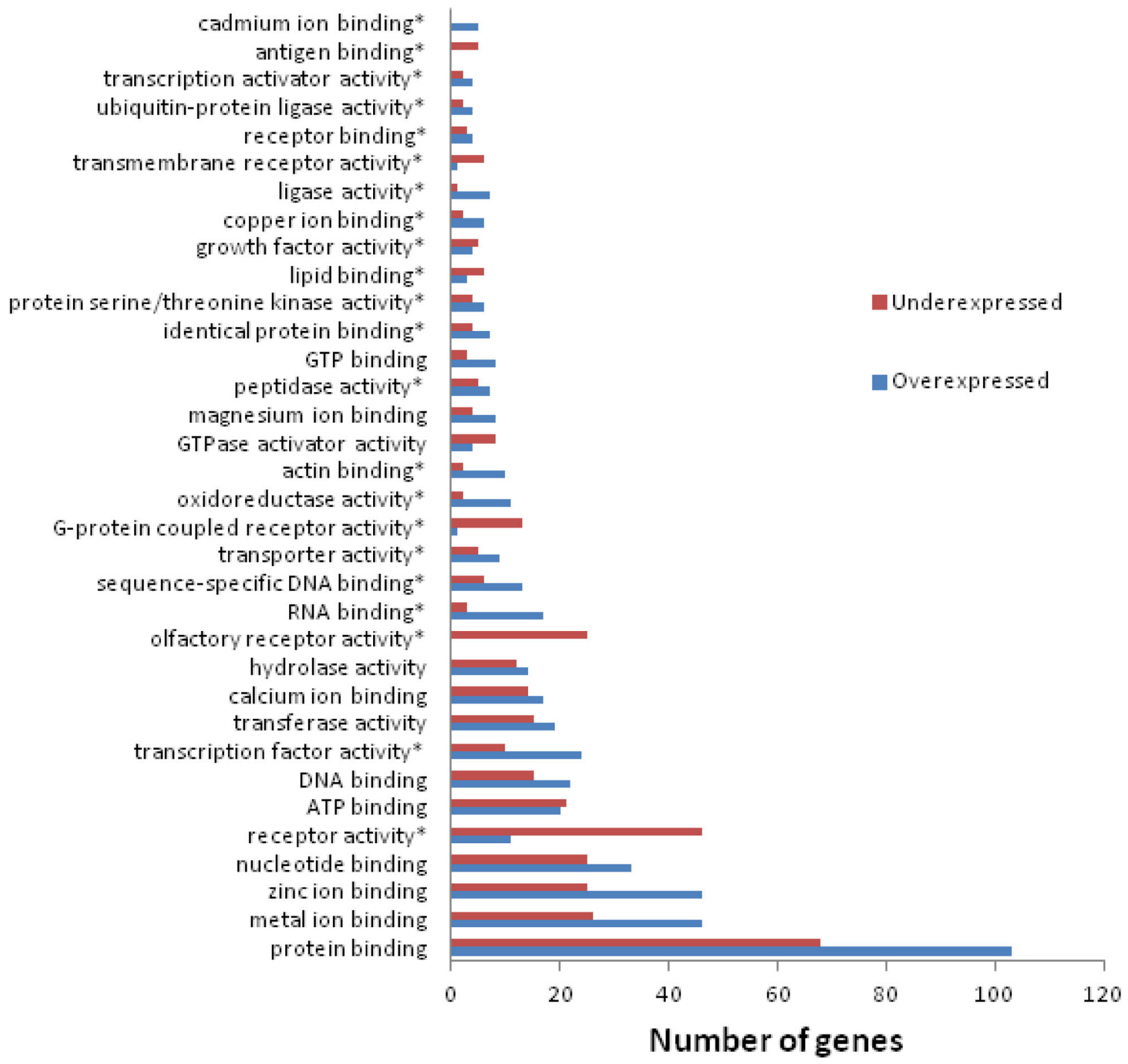

Figure 4. Gene Ontology (GO) categories denoting Molecular Function (MF) information for differentially expressed genes. Information is derived using Onto-Express (http://vortex.cs.wayne.edu/projects.htm). Diagram shows the number of underand over-expressed genes for each GO MF. The MF marked with stars denotes a statistically significant group $(p<0.05)$. Only the groups with a gene number $\geq 5$ are shown.

doi: 10.1371 /journal.pone.0084646.g004

divalent metal ions (i.e. zinc and calcium). There were four GO terms identified in this category: cadmium-, zinc-, calcium- and iron-ion binding genes (Table 4). As expected, many of metallothionein genes that are known to be induced by zinc 


\section{Figure 5}

\section{GO Biological Process}

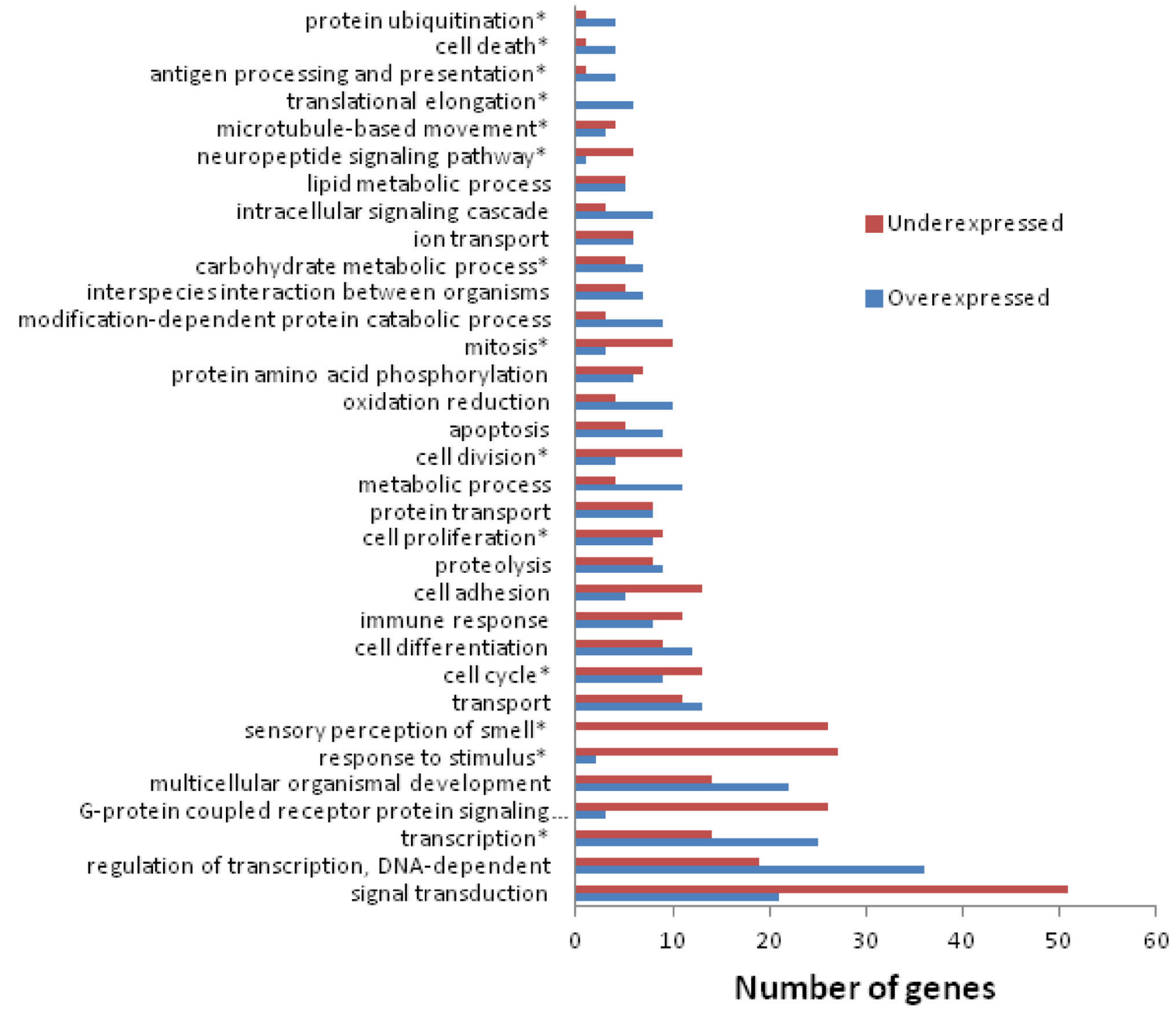

Figure 5. Gene Ontology (GO) categories denoting Biological Process (BP) information for differentially expressed genes. Information is derived using Onto-Express (http://vortex.cs.wayne.edu/projects.htm). Diagram shows the number of underand over-expressed genes for GO BP. The BP marked with stars denotes a statistically significant group $(p<0.05)$. Only the groups with a gene number $\geq 5$ are shown.

doi: 10.1371/journal.pone.0084646.g005

(MTA2, MT1X, etc.) and play important roles in the detoxification and transport of metal ions [44-46], were also induced by chronic cadmium exposure. Consistent with this observation, a previous study carried out on both immortalized human breast epithelial cells (HB2) and ER-negative breast cancer cells (MDA-MB-231) also reported the induction of multiple metallothionien genes (MT1F, MT1L, etc.) in response to cadmium exposure [47]. Furthermore, cadmium has been shown to induce the expression of metallothionein genes in other cancer cell types including prostate, testes, liver and lymphocytes [48-50]. Other metal binding genes that were elevated in response to chronic cadmium exposure included 
Table 4. GO Molecular Function: Metal ions.

\begin{tabular}{|c|c|c|c|}
\hline GO ID & Description & $\begin{array}{l}\text { No of } \\
\text { genes }\end{array}$ & Gene members \\
\hline GO:0046870 & cadmium ion binding & 5 & MT1X, MT1M, MT1H, MT1G, MT1F \\
\hline GO:0008270 & zinc ion binding & 71 & $\begin{array}{l}\text { ZNF552, CYHR1, ZNF90, RACGAP1, C20orf12, RNF183, PDLIM1, RNF4, MT2A, MT1X, MT1M, MT1H, MT1G, MT1F, } \\
\text { RING1, RNF135, CPN1, RNF8, RASA3, RABGGTA, MMP17, ZNF467, ZNF831, ADAM5P, ADAM15, FBLIM1, } \\
\text { PRKCZ, ZNF256, RFFL, RASGRP1, AGAP7, CBFA2T3, LASP1, SNAI3, LMCD1, AGAP4, FAM90A7, CA4, ZNF282, } \\
\text { ZNHIT2, ZFP36L2, FBX043, CA14, ZNF404, MEX3D, ZNF286A, JUB, RNF39, SOLH, SYTL5, TRIM17, ZDHHC9, } \\
\text { ZIM3, DPF3, EGR1, P2RX4, RUFY1, ZMIZ1, CIT, STAC2, ZNF709, TRIM49, CPO, ZNF296, RNF208, ATXN7, ZXDA, } \\
\text { RREB1, ZFAND2A, ZNF554, ZNF187 }\end{array}$ \\
\hline GO:0005509 & calcium ion binding & 31 & $\begin{array}{l}\text { AVIL, MYL12A, CRP, SYT7, VSNL1, MMP17, LRP2, CADPS, RASGRP1, SLC25A24, PLS3, PLA2G2A, CIB3, F8, } \\
\text { FKBP9, FAHD1, ATP2A3, EMR1, ASGR1, OCM, SGSH, ANXA3, ANXA2P2, ANXA2, AMY2A, EMR3, S100A10, } \\
\text { CD209, FSTL5, DAG1, CADPS2 }\end{array}$ \\
\hline GO:0005506 & iron ion binding & 2 & OGFOD1,NDUFS7 \\
\hline
\end{tabular}

Table 5. GO Biological Process: Cell Growth.

\begin{tabular}{llll}
\hline GO ID & Description & No genes & Gene members \\
\hline GO:0051301 & cell division & 15 & CCNE2, RNF8, WEE1, CKS1B, SETD8, CENPF, CCNF, CCNE1, CCNB1, SAC3D1, NCAPD2, BUB1, OIP5, NUSAP1, CIT \\
GO:0007049 & cell cycle & 22 & RACGAP1, CCNE2, PKMYT1, RNF8, WEE1, KAT2B, CKS1B, SETD8, CLSPN, MAPK6, CCNF, CCNE1, CCNB1, SAC3D1, \\
GCAPD2, BUB1, OIP5, NUSAP1, JUB, CIT, PCNP, PSRC1
\end{tabular}

Genes that are highlighted in bold are over-expressed, and the rest of the genes are under expressed.

doi: 10.1371 /journal.pone.0084646.t005

MMP17 (matrix metalloproteinase-17), ANXA3 (annexin A3) and STAC2 (Src homology 3 and cysteine-rich domaincontaining protein 2). The ability of cadmium to stimulate the expression of metal-binding proteins is likely associated with its ability to mimic divalent cations like calcium [51,52] and/or replace cations like zinc [53-57]. Specifically, cadmium has been shown to replace the zinc ions within the DNA binding domain of the estrogen receptor [58,59].

The second GO category that underwent further analysis involved cell growth, which included three GO terms: cell cycle, cell division and cell proliferation (Table 5). Previous studies have implicated cadmium in mediating breast cancer cell proliferation [19,60,61], and in line with these previous reports, our microarray analysis identified over 35 growth-related genes deregulated in cells chronically exposed to cadmium. Among these are CCNE1 (cyclin E1), CCNE2 (cyclin E2), CCNB1 (cyclin B1), and CCNF (cyclin F), all of which are direct regulators of the cell cycle. Cyclin E1 and 2- known to be involved in the regulation of the G1/S transition- are increased in cells chronically exposed to cadmium. Induction of cyclin E1 was also identified in our previous acute cadmium study on breast cancer cells [19]. On the other hand, cyclin B1 and F important for regulating the G2/M transition [62-68] are both down-regulated in the cadmium-adapted cells. The deregulation of any of these cyclins has been shown to be sufficient to promote cancer cell proliferation [41,67-73].
Furthermore, in addition to the cyclins, two other proteins that regulate the cell cycle - wee1 and BUB1- were also downregulated. Wee1 is a serine/threonine protein kinase that catalyzes the inhibitory tyrosine phosphorylation of cdk1/cyclin $B$ complex and coordinates the transition between DNA replication and mitosis, whereas BUB1 is a mitotic checkpoint serine/threonine-protein kinase.

Expression of a select number of genes from both $\mathrm{GO}$ categories (cadmium/metal binding and cell growth) were further evaluated using quantitative RT-PCR, and results confirmed that the specific genes were in fact deregulated in cells chronically exposed to cadmium in comparison to parental MCF-7 cells (Figure 6). While the qRT-PCR data were consistent with microarray data regarding the direction of change (up- or down-regulated), the relative fold changes found with qRT-PCR were much greater than those calculated in the microarray analysis. This is likely due to the higher noise:signal ratio associated with microarray analyses [74].

While this study was focused on ER-positive breast cancer cells, chronic cadmium exposure is also relevant to other cancer cell types. As noted earlier, some of the genes identified in this study were also deregulated in other cancer cells when exposed to cadmium [47-50]. A more recent study by Garrett and colleagues on acute ( 1 day) and chronic (13 days) cadmium exposure in kidney tubule cells also used microarray analysis to examine the gene expression profiles of cells 


\section{Figure 6}

A
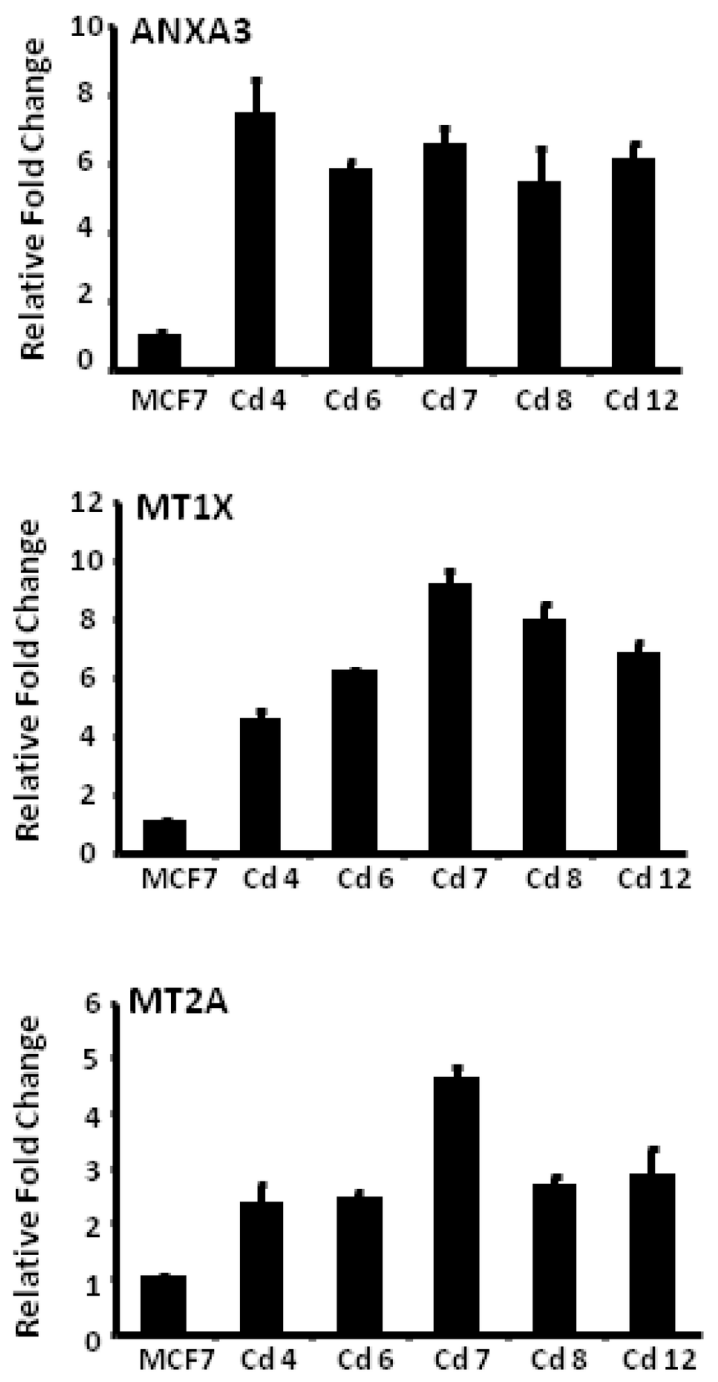

\section{B}
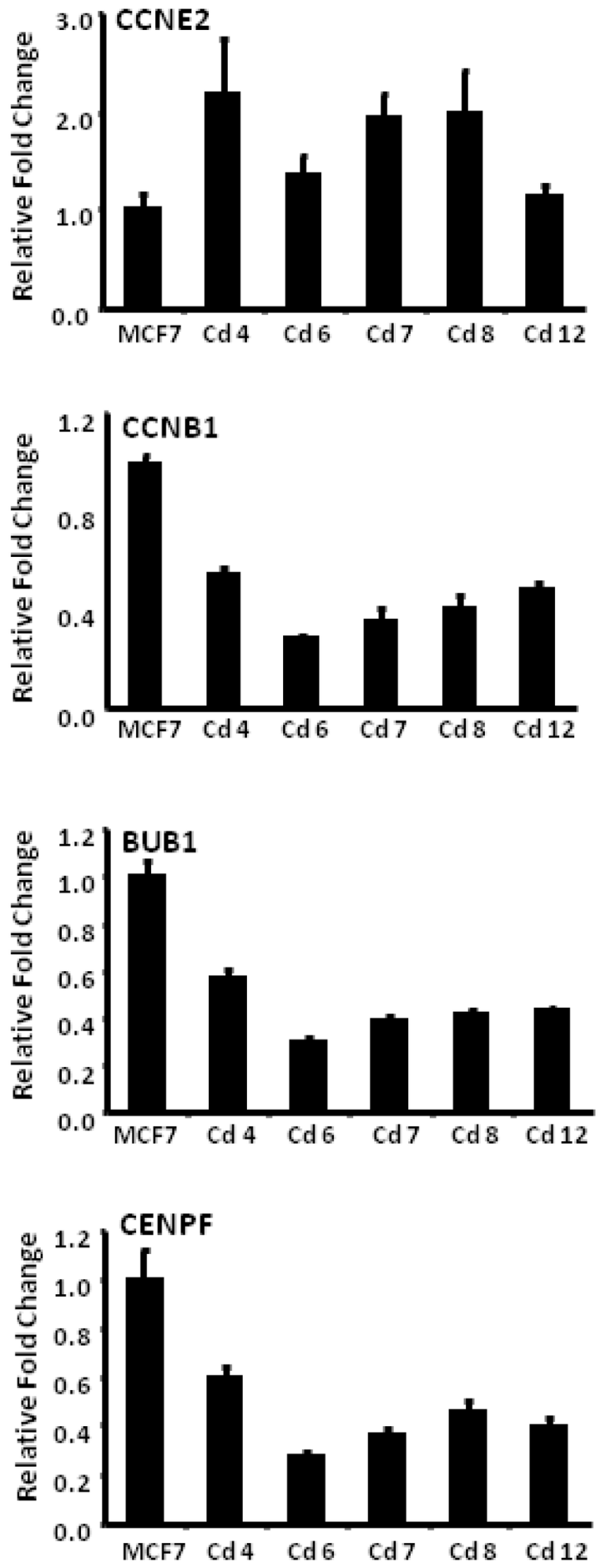

Figure 6. Confirmation of DE genes using quantitative RT-PCR. MCF-7 and MCF-7-Cd clonal cell lines (Cd-4, -6, -7, -8, and -12) were plated in $10 \mathrm{~cm}$ plates and total RNA was isolated for gene expression analysis using quantitative RT-PCR. Data are presented as relative fold changes with MCF-7 as the control and all fold changes are normalized to GAPDH (relative fold=2 ${ }^{\Delta \Lambda C t}$ gene/ $\triangle \triangle C t G A P D H)$ with $p<0.001$.

doi: 10.1371/journal.pone.0084646.g006 
Table 6. Summary of Gene Expression Fold Changes.

\begin{tabular}{lllllll}
\hline & MCF7 & Cd4 & Cd6 & Cd7 & Cd8 & Cd12 \\
\hline \multirow{2}{*}{ ANXA3 } & 1.00 & 7.38 & 5.77 & 6.54 & 5.44 & $6.05 \pm 0.056$ \\
& \pm 0.12 & \pm 1.09 & \pm 0.35 & \pm 0.47 & \pm 0.99 & \\
MT1X & 1.00 & 4.49 & $6.13 \pm$ & 9.10 & $7.89 \pm$ & $6.77 \pm 0.41$ \\
& \pm 0.08 & \pm 0.34 & 0.082 & \pm 0.51 & 0.62 & \\
MT2A & 1.00 & 2.37 & 2.42 & 4.58 & 2.64 & $2.88 \pm 0.49$ \\
& \pm 0.05 & \pm 0.32 & \pm 0.17 & \pm 0.23 & \pm 0.21 & \\
CCNE2 & 1.00 & 2.18 & 1.35 & 1.95 & 1.99 & $1.14 \pm 0.10$ \\
& \pm 0.16 & \pm 0.56 & \pm 0.19 & \pm 0.23 & \pm 0.43 & \\
CCNB1 & 1.00 & 0.55 & 0.28 & 0.35 & 0.41 & $0.49 \pm 0.03$ \\
& \pm 0.04 & \pm 0.02 & \pm 0.01 & \pm 0.05 & \pm 0.04 & \\
BUB1 & 1.00 & 0.57 & 0.30 & 0.39 & 0.41 & $0.43 \pm 0.01$ \\
& \pm 0.07 & \pm 0.04 & \pm 0.02 & \pm 0.02 & \pm 0.02 & \\
CENPF & 1.00 & 0.60 & 0.27 & 0.36 & 0.46 & $0.39 \pm 0.04$ \\
& \pm 0.12 & \pm 0.04 & \pm 0.02 & \pm 0.03 & \pm 0.04 & \\
\hline
\end{tabular}

White: Genes over-expressed in cadmium exposed cells; Gray: Genes downregulated in cadmium exposed cells.

doi: 10.1371/journal.pone.0084646.t006

exposed to cadmium [75]. Contrary to our study, the genes most significantly altered by chronic cadmium exposure did not include many metallothionein genes. However, the authors did identify LASP1 (LIM and SH3 protein 1) and ANXA2P2 (annexin A2 pseudogene 2) as being elevated and FAM182A (family with sequence homology 182) as being down-regulated, which is consistent with our results. We speculate that the observed differences between Garrett's study and ours are likely associated with several variable factors including cell type (kidney tubule cells versus breast cancer cells), cadmium concentration $\left(10^{-5} \mathrm{M}\right.$ versus $\left.10^{-7} \mathrm{M}\right)$, and length of cadmium exposure (13 versus $>180$ days). Unfortunately, the authors only reported a short list of genes with $p<0.001$, even though a much larger set of genes with $p<0.01$ was apparently generated, and it would be interesting to compare our results with this larger data set.

It is important to note that our study has only identified genes that were deregulated in all five clonal cadmium cells lines. As a result, there may be genes deregulated in only a subset of the cadmium clones that were not picked up in this study. Of particular interest is SDF-1, a gene that we have previously shown to be elevated in over $70 \%$ of the cadmium-adapted clonal cell lines generated [20]. Consistent with this, our

\section{References}

1. NTP (2011) Cadmium and cadmium compounds. Rep Carcinog 12: 80-83. PubMed: 21850119.

2. IARC (1993) Cadmium and cadmium compounds. IARC Monogr Eval Carcinog Risks Hum 58: 119-237. PubMed: 8022055.

3. Waalkes MP, Anver M, Diwan BA (1999) Carcinogenic effects of cadmium in the noble (NBL/Cr) rat: induction of pituitary, testicular, and injection site tumors and intraepithelial proliferative lesions of the dorsolateral prostate. Toxicol Sci 52: 154-161. PubMed: 10630567.

4. Waalkes MP, Anver MR, Diwan BA (1999) Chronic toxic and carcinogenic effects of oral cadmium in the Noble (NBL/Cr) rat: induction of neoplastic and proliferative lesions of the adrenal, kidney, prostate, and testes. J Toxicol Environ Health A 58: 199-214. PubMed: 10591488. microarray data also identified SDF-1 as one of the genes elevated in four of the five MCF-7-Cd cell lines used in this study (data not shown). Therefore, future analysis using less stringent criteria may identify additional genes relevant to cadmium-induced carcinogenesis.

This study is the first to identify gene expression patterns that differentiate breast cancer cells exposed to cadmium for prolonged periods of time versus those that have not. Our results demonstrate that prolonged cadmium exposure directly results in the deregulation of genes previously identified as being associated with breast cancer. While some of the deregulated genes were expected (cadmium/metal response genes), many are newly identified as cadmium-associated genes. Furthermore, these cadmium-associated genes are involved in multiple biological processes (i.e. cell growth and apoptosis) and molecular functions (i.e. cadmium/metal ion binding and transcription factor activity). The most intriguing finding from this study is that all five clonal cadmium cell lines share a common gene expression signature, suggesting that mammary tumors with high cadmium levels may share a similar expression profile (Figures 1 and 2). Therefore, future microarray analysis of mammary tumors with elevated cadmium levels will provide insight into the potential role of the bio-accumulated cadmium in breast cancer development and progression. Our results demonstrate the cellular and molecular impacts of cadmium on breast cancer carcinogenesis and emphasize the importance of studying the effects of chronic cadmium exposure on breast cancer.

\section{Supporting Information}

Table S1. Complete list of differentially expressed genes. (XLS)

\section{Acknowledgements}

We would like to thank Dr. Mary B. Sevigny for her insightful reading of the manuscript.

\section{Author Contributions}

Conceived and designed the experiments: MCL. Performed the experiments: ZL DBM EP MCL. Analyzed the data: ZL DBM EP MCL. Contributed reagents/materials/analysis tools: ZL MCL. Wrote the manuscript: ZL DBM EP MCL.
5. Waalkes MP, Diwan BA (1999) Cadmium-induced inhibition of the growth and metastasis of human lung carcinoma xenografts: role of apoptosis. Carcinogenesis 20: 65-70. PubMed: 9934851.

6. Waalkes MP, Rehm S, Cherian MG (2000) Repeated cadmium exposures enhance the malignant progression of ensuing tumors in rats. Toxicol Sci 54: 110-120. PubMed: 10746938.

7. Schwartz GG, Reis IM (2000) Is cadmium a cause of human pancreatic cancer? Cancer Epidemiol Biomarkers Prev 9: 139-145. PubMed: 10698473.

8. Satarug S, Garrett SH, Sens MA, Sens DA (2010) Cadmium, environmental exposure, and health outcomes. Environ Health Perspect 118: 182-190. PubMed: 20123617. 
9. Akesson A, Julin B, Wolk A (2008) Long-term dietary cadmium intake and postmenopausal endometrial cancer incidence: a population-based prospective cohort study. Cancer Res 68: 6435-6441. PubMed: 18676869

10. Cantor KP, Stewart PA, Brinton LA, Dosemeci M (1995) Occupational exposures and female breast cancer mortality in the United States. J Occup Environ Med 37: 336-348. PubMed: 7796202.

11. Martin MB, Reiter R, Pham T, Avellanet YR, Camara J et al. (2003) Estrogen-like activity of metals in MCF-7 breast cancer cells. Endocrinology 144: 2425-2436. doi:10.1210/en.2002-221054. PubMed: 12746304.

12. McElroy JA, Shafer MM, Trentham-Dietz A, Hampton JM, Newcomb PA (2006) Cadmium exposure and breast cancer risk. J Natl Cancer Inst 98: 869-873. doi:10.1093/jnci/djj233. PubMed: 16788160.

13. Strumylaite L, Bogusevicius A, Abdrachmanovas O, Baranauskiene D, Kregzdyte $\mathrm{R}$ et al. (2011) Cadmium concentration in biological media of breast cancer patients. Breast Cancer Res Treat 125: 511-517. doi: 10.1007/s10549-010-1007-8. PubMed: 20607602.

14. Ionescu JG, Novotny J, Stejskal V, Lätsch A, Blaurock-Busch E et al. (2006) Increased levels of transition metals in breast cancer tissue. Neuro Endocrinol Lett 27 Suppl 1: 36-39. PubMed: 16804515.

15. Byrne C, Divekar SD, Storchan GB, Parodi DA, Martin MB (2009) Cadmium--a metallohormone? Toxicol Appl Pharmacol 238: 266-271. doi:10.1016/j.taap.2009.03.025. PubMed: 19362102.

16. Garcia-Morales P, Saceda M, Kenney N, Kim N, Salomon DS et al. (1994) Effect of cadmium on estrogen receptor levels and estrogeninduced responses in human breast cancer cells. J Biol Chem 269: 16896-16901. PubMed: 8207012.

17. Johnson MD, Kenney N, Stoica A, Hilakivi-Clarke L, Singh B et al. (2003) Cadmium mimics the in vivo effects of estrogen in the uterus and mammary gland. Nat Med 9: 1081-1084. doi:10.1038/nm902. PubMed: 12858169

18. Stoica A, Katzenellenbogen BS, Martin MB (2000) Activation of estrogen receptor-alpha by the heavy metal cadmium. Mol Endocrinol 14: 545-553. doi:10.1210/me.14.4.545. PubMed: 10770491.

19. Siewit CL, Gengler B, Vegas E, Puckett R, Louie MC (2010) Cadmium promotes breast cancer cell proliferation by potentiating the interaction between ERalpha and c-Jun. Mol Endocrinol 24: 981-992. doi: 10.1210/me.2009-0410. PubMed: 20219890

20. Ponce E, Aquino NB, Louie MC (2013) Chronic Cadmium Exposure Stimulates SDF-1 Expression in an ERalpha Dependent Manner. PLOS ONE 8: e72639. doi:10.1371/journal.pone.0072639. PubMed: 24015267

21. Höfer N, Diel P, Wittsiepe J, Wilhelm M, Degen GH (2009) Dose- and route-dependent hormonal activity of the metalloestrogen cadmium in the rat uterus. Toxicol Lett 191: 123-131. doi:10.1016/j.toxlet. 2009.08.014. PubMed: 19703529.

22. Ali I, Penttinen-Damdimopoulou PE, Mäkelä SI, Berglund M, Stenius U et al. (2010) Estrogen-like effects of cadmium in vivo do not appear to be mediated via the classical estrogen receptor transcriptional pathway. Environ Health Perspect 118: 1389-1394. doi:10.1289/ehp.1001967. PubMed: 20525538.

23. Alonso-González C, González A, Mazarrasa O, Güezmes A, SánchezMateos S et al. (2007) Melatonin prevents the estrogenic effects of subchronic administration of cadmium on mice mammary glands and uterus. J Pineal Res 42: 403-410. doi:10.1111/j.1600-079X. 2007.00434.x. PubMed: 17439557.

24. Achanzar WE, Diwan BA, Liu J, Quader ST, Webber MM et al. (2001) Cadmium-induced malignant transformation of human prostate epithelial cells. Cancer Res 61: 455-458. PubMed: 11212230.

25. Haga A, Nagase $H$, Kito $H$, Sato $T$ (1996) Enhanced invasiveness of tumour cells after host exposure to heavy metals. Eur J Cancer 32A: 2342-2347. PubMed: 9038619

26. Irizarry RA, Bolstad BM, Collin F, Cope LM, Hobbs B et al. (2003) Summaries of Affymetrix GeneChip probe level data. Nucleic Acids Res 31: e15. doi:10.1093/nar/gng015. PubMed: 12582260

27. Saeed Al, Sharov V, White J, Li J, Liang W et al. (2003) TM4: a free, open-source system for microarray data management and analysis. BioTechniques 34: 374-378. PubMed: 12613259

28. Tusher VG, Tibshirani R, Chu G (2001) Significance analysis of microarrays applied to the ionizing radiation response. Proc Natl Acad Sci U S A 98: 5116-5121. doi:10.1073/pnas.091062498. PubMed: 11309499.

29. Benjamini Yah Y (1995) Controlling the False Discovery Rate: a Practical and Powerful Approach to Multiple Testing. Journal Statistical Soc B 57: 289-300.

30. Zhao YS, Zhu S, Li XW, Wang F, Hu FL et al. (2009) Association between NSAIDs use and breast cancer risk: a systematic review and meta-analysis. Breast Cancer Res Treat 117: 141-150. doi:10.1007/ s10549-008-0228-6. PubMed: 18979210.

31. Draghici S, Khatri $P$, Bhavsar $P$, Shah A, Krawetz SA et al. (2003) Onto-Tools, the toolkit of the modern biologist: Onto-Express, OntoCompare, Onto-Design and Onto-Translate. Nucleic Acids Res 31: 3775-3781. doi:10.1093/nar/gkg624. PubMed: 12824416.

32. Draghici S, Khatri P, Martins RP, Ostermeier GC, Krawetz SA (2003) Global functional profiling of gene expression. Genomics 81: 98-104. doi:10.1016/S0888-7543(02)00021-6. PubMed: 12620386.

33. Mosca E, Alfieri R, Merelli I, Viti F, Calabria A et al. (2010) A multilevel data integration resource for breast cancer study. BMC. Syst Biol 4: 76.

34. Kapushesky M, Adamusiak T, Burdett T, Culhane A, Farne A et al. (2012) Gene Expression Atlas update--a value-added database of microarray and sequencing-based functional genomics experiments. Nucleic Acids Res 40: D1077-D1081. doi:10.1093/nar/gkr913. PubMed: 22064864

35. Antila E, Mussalo-Rauhamaa $H$, Kantola M, Atroshi $F$, Westermarck $T$ (1996) Association of cadmium with human breast cancer. Sci Total Environ 186: 251-256. doi:10.1016/0048-9697(96)05119-4. PubMed: 8677430.

36. Benbrahim-Tallaa L, Tokar EJ, Diwan BA, Dill AL, Coppin JF et al. (2009) Cadmium malignantly transforms normal human breast epithelial cells into a basal-like phenotype. Environ Health Perspect 117: 1847-1852. doi:10.1289/ehp.0900999. PubMed: 20049202.

37. Bertucci F, Finetti P, Cervera N, Maraninchi D, Viens P et al. (2006) Gene expression profiling and clinical outcome in breast cancer. Omics 10: 429-443. doi:10.1089/omi.2006.10.429. PubMed: 17233555.

38. Huang E, Cheng SH, Dressman H, Pittman J, Tsou MH et al. (2003) Gene expression predictors of breast cancer outcomes. Lancet 361: 1590-1596. doi:10.1016/S0140-6736(03)13308-9. PubMed: 12747878.

39. Francois E, Wang DY, Fulthorpe R, Liss SN, Edwards EA (2003) DNA microarrays for detecting endocrine-disrupting compounds. Biotechnol Adv 22: 17-26. doi:10.1016/j.biotechadv.2003.08.005. PubMed: 14623040

40. Frasor J, Danes JM, Komm B, Chang KC, Lyttle CR et al. (2003) Profiling of estrogen up- and down-regulated gene expression in human breast cancer cells: insights into gene networks and pathways underlying estrogenic control of proliferation and cell phenotype. Endocrinology 144: 4562-4574. doi:10.1210/en.2003-0567. PubMed: 12959972

41. Keyomarsi K, Conte D Jr., Toyofuku W, Fox MP (1995) Deregulation of cyclin E in breast cancer. Oncogene 11: 941-950. PubMed: 7675453.

42. Kayaaltı Z, Aliyev V, Söylemezoğlu T (2011) The potential effect of metallothionein $2 \mathrm{~A}-5 \mathrm{~A} / \mathrm{G}$ single nucleotide polymorphism on blood cadmium, lead, zinc and copper levels. Toxicol Appl Pharmacol 256: 1-7. doi:10.1016/j.taap.2011.06.023. PubMed: 21767559.

43. Tekin D, Kayaaltı Z, Aliyev V, Söylemezoğlu T (2012) The effects of metallothionein $2 \mathrm{~A}$ polymorphism on placental cadmium accumulation: Is metallothionein a modifiying factor in transfer of micronutrients to the fetus? J Appl Toxicol 32: 270-275. doi:10.1002/jat.1661. PubMed: 21328412.

44. Jin T, Nordberg M, Nordberg GF (1992) Modulation of calciuria by cadmium pretreatment in rats with cadmium-metallothionein-induced nephrotoxicity. Toxicology 75: 29-37. doi: 10.1016/0300-483X(92)90123-V. PubMed: 1360715.

45. Nordberg M, Jin T, Nordberg GF (1992) Cadmium, metallothionein and renal tubular toxicity. IARC Sci Publ: 293-297. PubMed: 1303954.

46. Nordberg M, Nordberg GF (2000) Toxicological aspects of metallothionein. Cell Mol Biol (Noisy-Le-Grand) 46: 451-463. PubMed: 10774933.

47. Sirchia R, Longo A, Luparello C (2008) Cadmium regulation of apoptotic and stress response genes in tumoral and immortalized epithelial cells of the human breast. Biochimie 90: 1578-1590. doi: 10.1016/j.biochi.2008.06.011. PubMed: 18625282

48. Zhou T, Zhou G, Song W, Eguchi N, Lu W et al. (1999) Cadmiuminduced apoptosis and changes in expression of p53, c-jun and MT-I genes in testes and ventral prostate of rats. Toxicology 142: 1-13. doi: 10.1016/S0300-483X(99)00115-8. PubMed: 10647914.

49. Tully DB, Collins BJ, Overstreet JD, Smith CS, Dinse GE et al. (2000) Effects of arsenic, cadmium, chromium, and lead on gene expression regulated by a battery of 13 different promoters in recombinant HepG2 cells. Toxicol Appl Pharmacol 168: 79-90. doi:10.1006/taap.2000.9014. PubMed: 11032763

50. Lu J, Jin T, Nordberg G, Nordberg M (2001) Metallothionein gene expression in peripheral lymphocytes from cadmium-exposed workers. Cell Stress Chaperones 6: 97-104. doi:10.1379/1466-1268(2001)006. PubMed: 11599580.

51. Prozialeck WC, Niewenhuis RJ (1991) Cadmium (Cd2+) disrupts $\mathrm{Ca}(2+)$-dependent cell-cell junctions and alters the pattern of $\mathrm{E}$ - 
cadherin immunofluorescence in LLC-PK1 cells. Biochem Biophys Res Commun 181: 1118-1124. doi:10.1016/0006-291X(91)92054-N. PubMed: 1764062.

52. Prozialeck WC (2000) Evidence that E-cadherin may be a target for cadmium toxicity in epithelial cells. Toxicol Appl Pharmacol 164: 231-249. doi:10.1006/taap.2000.8905. PubMed: 10799334.

53. Predki PF, Sarkar B (1994) Metal replacement in "zinc finger" and its effect on DNA binding. Environ Health Perspect 102 Suppl 3: 195-198. doi:10.2307/3432177. PubMed: 7843097.

54. Bredenberg J, Nilsson L (2002) Conformational states of the glucocorticoid receptor DNA-binding domain from molecular dynamics simulations. Proteins 49: 24-36. doi:10.1002/prot.10195. PubMed: 12211013.

55. Predki PF, Sarkar B (1992) Effect of replacement of "zinc finger" zinc on estrogen receptor DNA interactions. J Biol Chem 267: 5842-5846. PubMed: 1556100.

56. Freedman LP, Luisi BF, Korszun ZR, Basavappa R, Sigler PB et al. (1988) The function and structure of the metal coordination sites within the glucocorticoid receptor DNA binding domain. Nature 334: 543-546. doi:10.1038/334543a0. PubMed: 3043231.

57. Buchko GW, Hess NJ, Kennedy MA (2000) Cadmium mutagenicity and human nucleotide excision repair protein XPA: CD, EXAFS and (1) H/ (15)N-NMR spectroscopic studies on the zinc(II)- and cadmium(II)associated minimal DNA-binding domain (M98-F219). Carcinogenesis 21: 1051-1057. doi:10.1093/carcin/21.5.1051. PubMed: 10783332.

58. Low LY, Hernández H, Robinson CV, O'Brien R, Grossmann JG et al. (2002) Metal-dependent folding and stability of nuclear hormone receptor DNA-binding domains. J Mol Biol 319: 87-106. doi:10.1016/ S0022-2836(02)00236-X. PubMed: 12051939.

59. Schwabe JW, Chapman L, Finch JT, Rhodes D (1993) The crystal structure of the estrogen receptor DNA-binding domain bound to DNA: how receptors discriminate between their response elements. Cell 75: 567-578. doi:10.1016/0092-8674(93)90390-C. PubMed: 8221895.

60. Yu X, Filardo EJ, Shaikh ZA (2010) The membrane estrogen receptor GPR30 mediates cadmium-induced proliferation of breast cancer cells. Toxicol Appl Pharmacol 245: 83-90. doi:10.1016/j.taap.2010.02.005. PubMed: 20153348.

61. Liu Z, Yu X, Shaikh ZA (2008) Rapid activation of ERK1/2 and AKT in human breast cancer cells by cadmium. Toxicol Appl Pharmacol 228: 286-294. doi:10.1016/j.taap.2007.12.017. PubMed: 18275979.

62. Chan TA, Hwang PM, Hermeking H, Kinzler KW, Vogelstein B (2000) Cooperative effects of genes controlling the $\mathrm{G}(2) / \mathrm{M}$ checkpoint. Genes Dev 14: 1584-1588

63. Malumbres M, Barbacid M (2005) Mammalian cyclin-dependent kinases. Trends Biochem Sci 30: 630-641. doi:10.1016/j.tibs. 2005.09.005. PubMed: 16236519.
64. Chang DC, Xu N, Luo KQ (2003) Degradation of cyclin B is required for the onset of anaphase in Mammalian cells. J Biol Chem 278: 37865-37873. doi:10.1074/jbc.M306376200. PubMed: 12865421.

65. Kong M, Barnes EA, Ollendorff V, Donoghue DJ (2000) Cyclin F regulates the nuclear localization of cyclin B1 through a cyclin-cyclin interaction. EMBO J 19: 1378-1388. doi:10.1093/emboj/19.6.1378. PubMed: 10716937.

66. Fung TK, Siu WY, Yam CH, Lau A, Poon RY (2002) Cyclin F is degraded during $\mathrm{G} 2-\mathrm{M}$ by mechanisms fundamentally different from other cyclins. J Biol Chem 277: 35140-35149. doi:10.1074/ jbc.M205503200. PubMed: 12122006.

67. D'Angiolella V, Esencay M, Pagano M (2013) A cyclin without cyclindependent kinases: cyclin $\mathrm{F}$ controls genome stability through ubiquitinmediated proteolysis. Trends Cell Biol 23: 135-140. doi:10.1016/j.tcb. 2012.10.011. PubMed: 23182110.

68. D'Angiolella V, Donato V, Forrester FM, Jeong YT, Pellacani C et al. (2012) Cyclin F-mediated degradation of ribonucleotide reductase M2 controls genome integrity and DNA repair. Cell 149: 1023-1034. doi: 10.1016/j.cell.2012.03.043. PubMed: 22632967.

69. Soria JC, Jang SJ, Khuri FR, Hassan K, Liu D et al. (2000) OverexpressOver-expression of cyclin B1 in early-stage non-small cell lung cancer and its clinical implication. Cancer Res 60: 4000-4004. PubMed: 10945597

70. Buckley MF, Sweeney KJ, Hamilton JA, Sini RL, Manning DL et al. (1993) Expression and amplification of cyclin genes in human breast cancer. Oncogene 8: 2127-2133. PubMed: 8336939.

71. Yasuda M, Takesue F, Inutsuka S, Honda M, Nozoe T et al. (2002) OverexpressOver-expression of cyclin B1 in gastric cancer and its clinicopathological significance: an immunohistological study. J Cancer Res Clin Oncol 128: 412-416. doi:10.1007/s00432-002-0359-9. PubMed: 12200597.

72. Korenaga D, Takesue F, Yasuda M, Honda M, Nozoe T et al. (2002) The relationship between cyclin B1 overexpressover-expression and lymph node metastasis in human colorectal cancer. Surgery 131: S114S120. doi:10.1067/msy.2002.119362. PubMed: 11821797.

73. Hwang HC, Clurman BE (2005) Cyclin E in normal and neoplastic cell cycles. Oncogene 24: 2776-2786. doi:10.1038/sj.onc.1208613. PubMed: 15838514

74. Venet D, Detours V, Bersini H (2012) A measure of the signal-to-noise ratio of microarray samples and studies using gene correlations. PLOS ONE 7: e51013. doi:10.1371/journal.pone.0051013. PubMed: 23251415.

75. Garrett SH, Clarke K, Sens DA, Deng Y, Somji S et al. (2013) Short and long term gene expression variation and networking in human proximal tubule cells when exposed to cadmium. BMC Med Genomics 6 Suppl 1: S2. doi:10.1186/1755-8794-6-S2-S2. PubMed: 23369406. 